\title{
Efficiency of Fishing Gears used in the Payra River at Dumki Upozila in Patuakhali District
}

\section{Mst. Niloy J1, Md. Mahmudul H¹, Md. Abu Sayed R, Sukrit KD² and Md. Sazedul H ${ }^{1 *}$}

${ }^{1}$ Department of Fisheries Technology, Patuakhali Science and Technology University, Bangladesh

2Department of Fisheries Technology, Bangladesh Agricultural University, Bangladesh

*Corresponding author: Md. Sazedul Hoque, Department of Fisheries Technology, Patuakhali Science and Technology University, Dumki, Patuakhali-8602, Bangladesh, Tel: +8801716244719; Email: sazedul.fst@pstu.ac.bd

\section{Abstract}

Payra River is one of the most important coastal rivers in the Patuakhali district which serve as feeding, breeding and nursing ground for the different fish species. The present study was conducted to estimate the gear used in the Payra River and species composition with this gear during the period of 1st august 2017 to July 2018. The data were collected every week in face to face interview through the study period. A wide variety of fishing gears were operated throughout the year in the study area for commercial fishing. From the study, a total of eighteen types of fishing gear were identified under nine major categorizes described as Gill nets (Current jal, Dandi jal, Chandi jal, Poa jal, Ramsos jal, Ayre jal), Seine net (Ber jal), Fixed purse net (Behundi Jal and Chargora jal), Lift nets (Dharma jal), Push net (Thela jal and Moiya jal) ,Cast net (Jhaki jal) Traps (Pungus Chai, Anta), Hook \& Line ( Chip Barshi, Chara Barshi) and Wounding gear (Koach). Among the fishing gears higher amount of fish were caught by Chandi Jal (36.5 kg) and lower amount of fish were caught by Chip borshi (1.5 kg). In the Dandi Jal, Poa Jal, Current Jal, Ramsos jal, Ayre Jal, Behundi Jal, Chargara Jal, Ber Jal, Thela Jal, Moiya Jal, Dharma Jal, Jhaki Jal, Pangus chai, Anta, Chara borshi and koach the catch per day was identified $8.5 \mathrm{~kg}, 12 \mathrm{~kg}, 25.5 \mathrm{~kg}$, $13 \mathrm{~kg} 15.4 \mathrm{~kg}, 19.5 \mathrm{~kg}, 12.5 \mathrm{~kg}, 17.7 \mathrm{~kg}, 2.5 \mathrm{~kg}, 4.5 \mathrm{~kg}, 6.5 \mathrm{~kg}, 2.8 \mathrm{~kg}, 5 \mathrm{~kg}, 2.25 \mathrm{~kg}, 7 \mathrm{~kg}$ and $2.5 \mathrm{~kg}$ respectively. Some of the gears were selective for a particular species like chandi jal, poa jal, ramsos jal and ayre jal. Behundi Jal and Ber jal were found to catch fish irrespective of their size or species and destroy the habitat of the wild species. An awareness or training program should be conducted to the fishermen to create awareness of the long-term effects of different fishing gears and to impart knowledge of fishing laws.

Keywords: Fishing Gear; Fish Diversity; Payra River; Gill Net 


\section{International Journal of Oceanography \& Aquaculture}

Abbreviations: CI: Cross-check Interviews; UFO: Upazila Fisheries Officer; DFO: District Fisheries Officers; NGO: Non-Governmental Organisation.

\section{Introduction}

Bangladesh is topographically a deltaic plain crisscrossed by innumerable rivers and rivulets and has a great fisheries potential. Riverine fishing areas comprise nearly one fifth of the entire fishing area of 4.9 million ha of the country [1]. It is also rich in the diversity of various fish species and other important aquatic species. Hence, it is ranked fourth in fish biodiversity in Asia behind China, India and Thailand [2], with approximately 800 species of fresh, brackish and marine waters [3]. In our country coastal water fishery resources play an important role in the economy and food habits of the people of Bangladesh. Payra River is a kind of running water body which moving to a lower level in a channel on land in the country of Bangladesh and by the name of Burishwar river finally it falls into the Bay of Bengal. Payra River has rich fishing resources which are the essential part not only the fisherman but also for the people living surrounding this river. It provides natural spawning grounds and nursery grounds for many commercially important species of aquatic biota and a significant portion of the country's fisheries production is dependent on this coastal river [4]. Its center lies at a latitude of $22^{\circ} 28^{\prime}$ and longitude of $90^{\circ} 20^{\prime}$ and it has an elevation of $1 \mathrm{~m}$ above sea level.

Fishing gear is any form of equipment, implement, tool or mechanical device used to catch, collect or harvest fish. The major categories of fishing gears that are regularly used in Bangladesh can be counted as the following: fishing nets, fishing traps, hooks and lines, wounding gears and fish aggregation device [5]. Various types of materials are used to make these fishing gears include netting twine, plastic structural and fasteners, clips and swivels, ropes, steel wire ropes, iron, combination wire ropes, purse rings, polyester, polyethylene, nylon, cotton, polypropylene, mixed fibers, floats and sinkers, bamboo, wood, etc [6].

Different types and form of gears have been operated in the Payra River to exploit wild fishes. The intensity of use of any form of gear in a river is dependent on the intensity of target fish population presumed to be available in that river. Some of the gears are selective for a particular species, whereas other account for a number of species caught during operation giving multi-species nature of the fishing. Only a few studies have been undertaken on the status of resources as well as the causes of declining resources in the Payra River. The intensity of fishing gears, mesh sizes and catch per unit effort are good indicators of the status of exploitation level of river.

There are some destructive fishing gear in this region by this gear a wide range sizes of finfish and shellfish species including juveniles are catches for that reason it is an efficient fishing gear to the fisherman, but most harmful for fish biodiversity. These types of gear are widely used in the Payra River for collecting small fish mostly juvenile of commercially valuable species [4]. So this study aims to identify the harmful fishing gear, its negative impact on fish biodiversity and to develop management strategies for conservation measures.

From the above discussion under the title following objective were set.

a) To know about different types of fishing net used and their catch composition in Payra River.

b) To identify harmful fishing gear and its negative impacts on fish biodiversity and

c) To know the mode of operation of different types of net used in Payra River.

\section{Materials and Methods}

\section{Study Area}

The study was conducted for a period of 12 months from 1st August 2017 to July 2018 at the two station of the Payra River. One is adjacent to the Patuakhali sadar Upazila and another is near to the Dumki upazilla under the Patuakhali district (Figures $1 \& 2$ ).

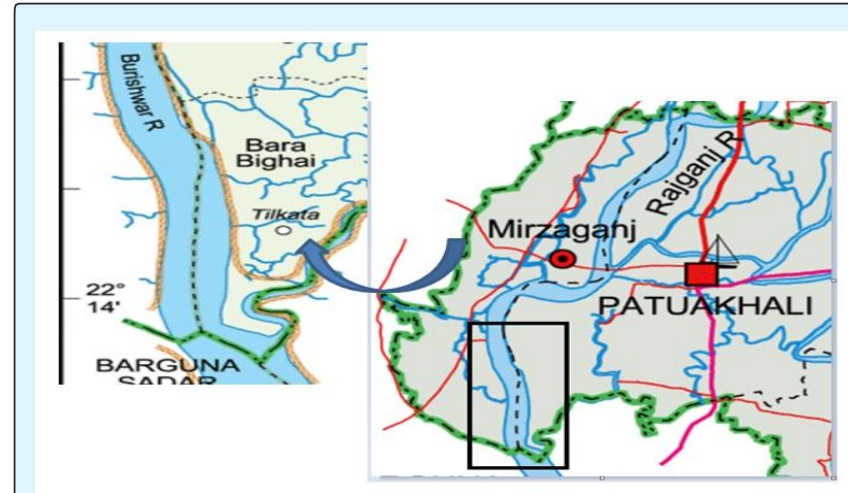

Figure 1: Geographical position of Payra River (study area). Figure 2: Map of study site.

\section{Data Collection \& Analysis}

The present study was conducted to assess fishing gears used in Payra River during the post monsoon period. 


\section{International Journal of Oceanography \& Aquaculture}

For collection of primary data sixty fishermen were selected randomly from professional, seasonal and subsistence fishermen groups from Patuakhali sadar upazila and Dumki Upazila region. Interviews were conducted through face to face interview method and also data were collected once weekly throughout the study period by using semi-structured open ended questions. Secondary data were collected from various sources such as relevant thesis paper and local organization. Crosscheck Interviews (CI) were conducted with key informants such as Upazila Fisheries Officer (UFO), District Fisheries Officers (DFO) and relevant GO and NGO officers and staffs. Data was analyzed by simple statistical method and Microsoft excel.

\section{Results}

Study showed that variety of fishing Gear operates during the post monsoon period in the Payra River for commercial fishing. Most of the fishing methods in the study area were traditional and simple. From the study, total eighteen types of fishing gear were identified under nine major categorizes described as Gill nets (Current jal, Dandi jal, Chandi jal, Poa jal, Ramsos jal, Ayre jal), Seine net (Ber jal), Fixed purse net (Behundi Jal and Chargora jal), Lift nets (Dharma jal), Push net (Thela jal and Moiya jal), Cast net (Jhaki jal), Traps (Pungus Chai, Anta), Hook \& Line ( Chip Barshi, Chara Barshi) and Wounding gear (Koach).

\section{Types and Characteristics of Fishing Net Operated in the Study Area}

Various types of fishing gears are used in the Payra River. The building materials and mode of the operation of the gear differ from one to another; even their catch composition was differing from one to another. Details about different types of fishing gear are given in Table 1 .

\begin{tabular}{|c|c|c|c|c|c|c|c|}
\hline Gear Types & Local Name & $\begin{array}{c}\text { Mesh Size } \\
(\mathrm{cm})^{* *}\end{array}$ & Prize (BDT) & $\begin{array}{l}\text { Operation } \\
\text { Depth(m) }\end{array}$ & \begin{tabular}{|c|} 
CPUE*** \\
(Kg/effort)
\end{tabular} & Netting Materials & $\begin{array}{l}\text { Life } \\
\text { Span }\end{array}$ \\
\hline \multirow{6}{*}{ Gill Net } & Chandi Jal* & $4.5-8.5$ & $35000-40000$ & $1-20$ & 36.5 & Nylon rope, mixed fiber & $2-3$ \\
\hline & Dandi Jal & $1.25-3.25$ & $25000-30000$ & $2-12$ & 8.5 & Polyamide monofilaments & $3-4$ \\
\hline & Poa Jal & $2.25-4.5$ & $25000-35000$ & $2-10$ & 12 & Monofilament nylon & $2-3$ \\
\hline & Current Jal & $1.25-4.25$ & $35000-40000$ & $1-20$ & 25.5 & $\begin{array}{l}\text { Poly amide, Polypropylene } \\
\text { nylon }\end{array}$ & $2-3$ \\
\hline & Ramsos Jal & $1.75-4.25$ & $250000-30000$ & $2-8$ & 13 & Polyamide, polyester & $2-3$ \\
\hline & Ayre Jal & $4-8.5$ & $30000-40000$ & $2-18$ & 15.4 & Polyvinyl chloride & $3-4$ \\
\hline \multirow{2}{*}{$\begin{array}{c}\text { Fixed purse } \\
\text { Net }\end{array}$} & Behundi Jal & $0.5-1.75$ & $25000-30000$ & $2-15$ & 19.5 & Twine fiber, nylon rope. & $2-3$ \\
\hline & Chargara Jal & $0.5-1.75$ & $15000-20000$ & $1-6$ & 12.5 & $\begin{array}{l}\text { Polypropylene nylon rope, } \\
\text { cotton. }\end{array}$ & $2-3$ \\
\hline Seine Net & Ber Jal & $0.5-1.75$ & $40000-50000$ & $2-12$ & 17.7 & $\begin{array}{c}\text { Synthetic nylon fiber, mixed } \\
\text { fiber. }\end{array}$ & $4-5$ \\
\hline \multirow{2}{*}{ Push Net } & Thela Jal & $0.25-1$ & $400-500$ & $1-3$ & 2.5 & Polyamide nylon rope & $1-3$ \\
\hline & Moiya Jal & $0.25-1$ & $1000-1500$ & $1-5$ & 4.5 & Polyvinyl chloride & $2-3$ \\
\hline Lift Net & Dharma Jal & $0.5-1.25$ & $4000-5000$ & $1-8$ & 6.5 & Polyamide nylon fiber & $1-2$ \\
\hline Cast Net & Jhaki Jal & $0.5-1.5$ & $3000-5000$ & $2-6$ & 2.8 & Nylon rope, mixed fiber & $4-5$ \\
\hline \multirow{2}{*}{ Traps } & Pangus chai & MO:05 & $500-700$ & $1-4$ & 5.0 & Bamboo splits, suta & $1-2$ \\
\hline & Anta & MO:05 & $300-500$ & $1-3$ & 2.5 & Bamboo sticks & $1-2$ \\
\hline \multirow{2}{*}{$\begin{array}{c}\text { Hook and } \\
\text { line }\end{array}$} & Chip borshi & & $500-1000$ & $2-6$ & 1.5 & Iron, bamboo sticks & $2-3$ \\
\hline & Chara borshi & & $10000-15000$ & $2-8$ & 7.0 & Nylon ropes, hooks & $1-2$ \\
\hline $\begin{array}{c}\text { Wounding } \\
\text { gear }\end{array}$ & Koach & & $300-500$ & $2-4$ & 2.5 & Bamboo, sharp iron & $2-3$ \\
\hline
\end{tabular}

*Jal= Fishing net, ${ }^{* *} \mathrm{Cm}=$ Centimetre, ${ }^{* * *} \mathrm{CPUE}=$ Catch per Unit Effort

Table 1: Types of nets, mesh size, prize, operation depth, netting materials and life span of the fishing gear.

In the study period the availability of fishes is higher because it is post monsoon period. For that reason higher amount of fishes are caught during this period. The amount of fishes caught per day by the fishing gear is shown in Figure 3. 


\section{International Journal of Oceanography \& Aquaculture}

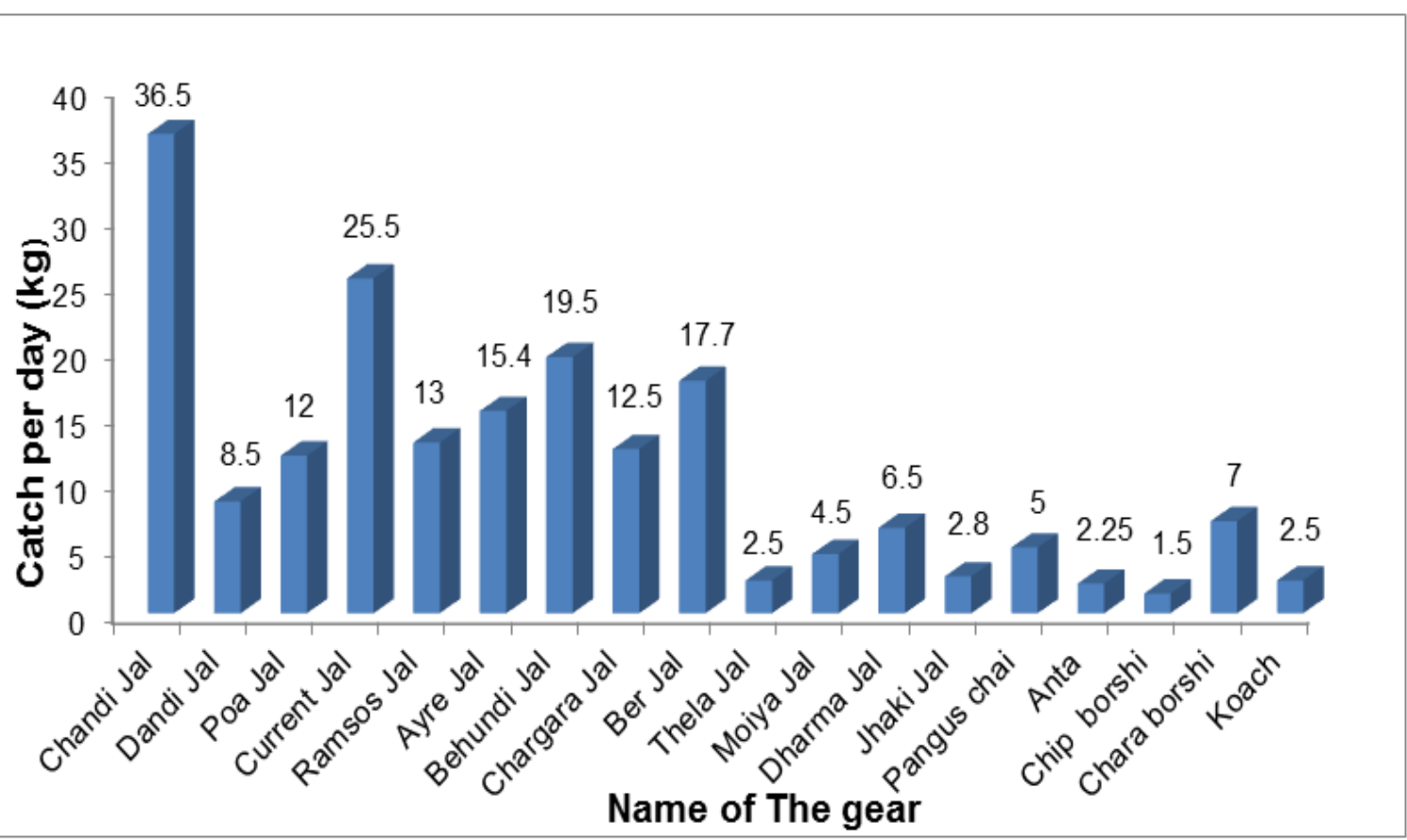

Figure 3: Gear wise catch composition per day.

In Figure 3 identified higher amount of fish ware caught by Chandi Jal (36.5 kg) And lower amount of fish were caught by Chip borshi $(1.5 \mathrm{~kg})$. In the Dandi Jal, Poa Jal, Current Jal, Ramsos jal, Ayre Jal, Behundi Jal, Chargara Jal, Ber Jal, Thela Jal, Moiya Jal, Dharma Jal, Jhaki Jal, Pangus chai, Anta, Chara borshi and koach the catch per day was identified $8.5 \mathrm{~kg}, 12 \mathrm{~kg}, 25.5 \mathrm{~kg}, 13 \mathrm{~kg} 15.4 \mathrm{~kg}$, $19.5 \mathrm{~kg}, 12.5 \mathrm{~kg}, 17.7 \mathrm{~kg}, 2.5 \mathrm{~kg}, 4.5 \mathrm{~kg}, 6.5 \mathrm{~kg}, 2.8 \mathrm{~kg}, 5 \mathrm{~kg}$, $2.25 \mathrm{~kg}, 7 \mathrm{~kg}$ and $2.5 \mathrm{~kg}$ respectively. Descriptive study about these fishing net are describe bellow.

Gill Net: Gill netting is a common fishing method used by commercial and artisanal fishermen of all the rivers of Bangladesh as well as in these areas. Locally it is called Fash Jal. The net was drifted with water current and the gill of fish is trapped in the mesh of the net. Floats and sinkers are attached and plastic ropes are used as head ropes and foot ropes. Gillnets have a high degree of size selectivity. Six types of gill nets were widely operated in the study area viz., Chandi jal, poa jal, ramsos jal, ayre jal, current jal and dandi jal. Their descriptive study is shown below.

Chandi Jal: Chandi jal is also known as Ilish jal and one of the common gill net operated in the Payra River. Mesh size of this net was observed 4.5 to $8.5 \mathrm{~cm}$. The length of the net was identified $700 \mathrm{~m}$ to $800 \mathrm{~m}$ and width was 13 to $15 \mathrm{~m}$. The net was constructed by polyamide monofilaments, nylon rope, mixed fiber (Table 1). The net was operated from the boat by 5 to 6 persons and generally used in the whole year. Mainly Hilsa (Tenualosa ilisha), Poa (Otolithoides pama) and Taposhi (Polynemus paradiseus) were caught by the net.

Dandi Jal: Dandi Jal is a gill net made of polyamide monofilaments and nylon rope. The length of the net varies from 150 to $200 \mathrm{~m}$ and the width was recorded 8 to $10 \mathrm{~m}$. The net was rectangular in shape and the mesh size of the net was found 1.25 to $3.25 \mathrm{~cm}$ (Table 1). The net was operated by 3 to 4 persons from the boat in both day and night. Generally Tular dandi (Sillaginopsis panijus) Poa (Otolithoidespama) and Bele (Glossogobius giuris) were the main species caught by net.

Poa Jal: Poa jal is a gill net made of polyamide monofilaments nylon rope. The length of the net varies from 550 to $650 \mathrm{~m}$ and the width was identified 5 to $7 \mathrm{~m}$. The net was found rectangular in shape and the mesh size of the net was recorded 2.25 to $4.5 \mathrm{~cm}$ (Table 1 ). Need 3 to 4 persons for operated this net from the boat at day and night. Poa (Otolithoidespama), Taposhi (Polynemus 


\section{International Journal of Oceanography \& Aquaculture}

paradiseus), Hilsa (Tenualosa ilisha) and Faisha (Setipinna phasa) were the main species caught by net.

Ramsos Jal: Ramsos jal is a gill net made of Polyamide, polyester and occasionally by nylon rope. The length of the net varies from 600 to $700 \mathrm{~m}$ and the width 4.5 to $6 \mathrm{~m}$. The net was found rectangular in shape and the mesh size of the net was identified 1.75 to $4.25 \mathrm{~cm}$ (Table 1). Both floats and sinkers were attached with net and mainly operated by 5 to 6 persons from the boat in both day and night. Taposhi (Polynemus paradiseus), Poa (Otolithoides pama) and Cheua (Pseudapocryptes elongates) were the main species caught by net.

Ayre Jal: Ayre jal is a gill net made of polyamide monofilaments and nylon rope. The length of the net varies from 200 to $250 \mathrm{~m}$ and the width was identified 10 to $12 \mathrm{~m}$. Mesh size of the net was identified 4 to $8.5 \mathrm{~cm}$ (Table 1). The net was operated by 4 to 5 persons from the boat in both day and night. Ayre (Sperata aor) Pangus (Pangasius pangasius) and Coral (Lates calcarifer) were the main species caught by net.

Current Jal: Current Jal is a gill net made of polyamide monofilaments, polypropylene and nylon rope. The length of the net varies from 600 to $800 \mathrm{~m}$ and the width was observed 9 to $12 \mathrm{~m}$. Mesh size of the net recorded 1.25 to $4.25 \mathrm{~cm}$ (Table 1). The net was drifted by 4 to 5 persons from the boat in both day and night when water current is low. It is one kind of destructive fishing gear because huge number of juvenile and other small sizes fishes of different species was caught by this gear which was identified during collection of data. Hilsa (Tenualosa ilisha), Poa (Otolithoides pama), Ayre (Sperata aor) Pangus (Pangasius pangasius) and Faisha (Setipinna phasa) were the main species caught by net.

Seine Net: Seine net has very long wings and a towing rope. The nets are of various lengths and come with or without bags for catching and are locally called Ber Jal. If the size is too big, it is called Jagot Berjal. Fish are captured by surrounding a certain area and towing the gear over the area with both ends to a fixed point on the shore or on a fishing vessel.

Ber Jal: It is a fine mesh size seine net which is commonly used in the Payra River. It was found large in size, usually 600 to $650 \mathrm{~m}$ long and 8 to $10 \mathrm{~m}$ wide with a mesh size 0.5 and $1.75 \mathrm{~cm}$ (Table 1). Having floats and weights, need 6 to 8 people to operate the net. After surrounding the part of a water body with this net, the two ends of the net were drawn together and the ground rope is hauled up from the center of the water body to catch the fish. Although it catches almost all types of fishes among them Juvenile Pangus (Pangasius pangasius), Poa (Otolithoides pama) and Juvenile Hilsa (Tenualosa ilisha).

Fixed Purse Net: Fixed purse net is a common type of purse seine, named such because along the bottom are a number of rings. Locally known as Behundi Jal, is used in the shallow region of the river to catch different types of fish.

Behundi Jal: The net is also locally known as 'Badhar Jal/ Benti Jal'. Behundi Jal is a purse or conical in shape made up of nylon ropes and twine fiber and has two extensions. The length of the net was identified 15 to $25 \mathrm{~m}$ and width of mouth of the net was found 9 to $12 \mathrm{~m}$. The mesh size at the mouth 2.5 to $3.25 \mathrm{~cm}$ and at the end of the pouch was 0.5 to $1.75 \mathrm{~cm}$ (Table 1). The front side was wide and opened by using two bamboo poles. The net was usually set in the middle of the river and fish was trapped in the center pouch of the net. All types of small to large fish are caught by this net. Thus it is most destructive fishing gear in this region. The net is operated in all season even at ban period.

Chargora Jal: Chargora jal was observed rectangular shaped net and operate at near bank of the river. The net was constructed by polyamide, nylon rope and cotton. It was observed that the net was set before high tide and hauled in low tide and thus it has no float and sinker. The length of the net was recorded 200 to $250 \mathrm{~m}$ and width was 4 to $5 \mathrm{~m}$. The mesh size of the net was found 0.5 to $1.75 \mathrm{~cm}$ (Table 1). 2 to 3 persons were required to operate this net. All types of small and large fish are caught by this type of net.

Lift Net: Lift net is a hand operated and portable net generally used in the shallow region of the river to catch small fish. A lift net has an opening which faces upwards. The net is first submerged to a desired depth and then lifted or hauled from the water. It can be lifted either manually (hand lift net) or mechanically (shore-operated lift net) and can be operated on a boat (boat-operated lift net. This net is locally named as dharma jal.

Dharma Jal: The common shape of the net is square. The length of the net was found 8 to $10 \mathrm{~m}$ and width was 6 to $8 \mathrm{~m}$ (Table 1). It was observed that the net was fitted with two bamboo strips arranged in cross-bars and connected at the four corners of the net. A fisherman dips the net in water only in daytime where river current is gentle and pushes it forward and then abruptly lifts it up by another 


\section{International Journal of Oceanography \& Aquaculture}

bamboo lever. Occasionally, a rope is used to facilitate the manipulation of the net. The mesh size of the net was recorded 0.5 to $1.25 \mathrm{~cm}$. The main species caught by the net were Baila (Glossogobius giuris), Taki (Channa punctatus), Shol (Channa striatus), Koi (Anabas testudineus), Gulsha (Mystus cavasius), Tengra (Mystatus vittatus), Prawn and Baim (Mastacembelus armetus).

Cast Net: It is a common net in Bangladesh and used in Payra River. Cast nets are conical-circular nets, the edge of which is weighted with iron while the conical end is tied to a throwing/hauling rope. The throwing rope also serves as hauling rope. It is operated manually. Cast net, locally known as Jhaki jal/Khapla jal, is used in the shallow region of the river to catch different types of fish.

Jhaki Jal: The net is conical shaped where it was recorded 3 to $5 \mathrm{~m}$ long form anterior part to the posterior end with 6 to $9 \mathrm{~m}$ in diameter of the mouth. A rope of about $5-7 \mathrm{~m}$ length was connected to the apex of the conical net. The mesh size of the net varies from $0.5-1.5 \mathrm{~cm}$ (Table 1$)$. One person can operate this net as the weight of the net was 3 to $6 \mathrm{~kg}$. It was observed that when the net was casted it spreads out over the water surface circularly and when lifted it comes out in conical form. The main species caught by the net were Bata (Labeo bata), Taposhi (Polynemus paradiseus), Koi (Anabas testudineus), Poa (Otolithoides pama) and Prawn.

Drag Nets/Push Nets: This is a term which can be applied to any net which is dragged or hauled across a river or along the bottom of a lake or sea. Drag nets/push nets are held apart with triangular bamboo frame and pushed manually to fish in the traditional waters of river, beels and floodplains.

Thela Jal: Thela jal is a triangular shaped push net constructed by polyamide mono-filament nylon rope with an extended handle of two bamboo poles are fixed at an angle of $30^{\circ}$. Length of the net was identified 2 to $4 \mathrm{~m}$ and width was 1 to $3 \mathrm{~m}$ having a mesh size of 0.25 to $1.0 \mathrm{~cm}$ (Table 1). The triangular portion of the net was lowered and pushed one person forward along the bed of the shallow water areas. All small size fish was caught by it among them Gulsha (Mystus cavasius), Koi (Anabas testudineus), Chewa (Odontambyoopus rubicundus), Poa (Otolithoides pama), Baim (Mastacembelus armetus) and Prawn were caught.

Moiya Jal: It was observed that Moiya jal was a rectangular shaped net, upper side was attached with a horizontal bamboo pole and lower side has many pockets and sunk under the water by the support of iron attached to each pocket. Length of the net was identified 3 to $4 \mathrm{~m}$, width 2 to $3 \mathrm{~m}$ and mesh size 0.25 to $1 \mathrm{~cm}$ (Table 1 ). Small to medium sized fishes were caught by this net. But the net was mainly used to catch prawn and can be used in the whole year. It is used in all seasons and 1 to 2 fishermen are needed to operate this net.

Fishing Traps: A fish trap is a trap used for fishing. Fishing traps are mostly made by bamboo or wooden material and used by professional and nonprofessional fishermen. Sometimes it made by iron frame with net. There were two types of traps was identified from the study area viz. Pangas chai and Anta.

Pangus Chai: Pangus chai is a large box type trap made of bamboo splits having two or three trap door in each of the side of the trap. Its length was 3 to $5 \mathrm{~m}$ and width was about 2 to $3 \mathrm{~m}$. The mesh size of the gear was $20 \mathrm{~cm}$ in the mouth opening. The trap is suspended under water just below surface level by using a bamboo pole or by a boat. Different types of bait are used to catch the small size pangus (Pangasius pangasius). The catch composition of the gear was 2-4 kg per day. Due to the bait large number of small fish of different species is attracted to the trap which makes this trap a destructive one for fish biodiversity. This gear is used for household purposes.

Anta: Anta is one kind of fishing traps made of bamboo sticks are used widely in rural Bangladesh. These are of various shaped chambers essentially having contrivances for the fishes to enter. Escape is prevented by automatic labyrinths or retarding devices. The mesh size of the gear was $2.5 \mathrm{~cm}$ in the mouth opening. The length and width of the catch composition of the gear was $1 \mathrm{~kg}$ per day. The main species caught by the gear is Poa (Otolithoides pama), Koi (Anabas testudineus), and Tit Punti (Puntius tieto). The catch composition of the gear is $1 \mathrm{~kg}$ per day. This gear is used for household purposes but it is destructive for fish biodiversity of the Payra River.

Hooks and Lines: Hooks are manufactured in a wide range of size, and the gap between the point and the shank appears to be the dimension, which determines the size range of fish caught by a particular hook. The most familiar type of manufactured steel hook is "J" shaped, which is mostly used for hook and line fishing. Two types of hooks and lines were found in the study area.

Sip Barshi: Sip or Barshi is a very simple barbed hook tied with one end of a line and the other end with a bamboo stick (Table 1). Above the hook there is a float 


\section{International Journal of Oceanography \& Aquaculture}

used to drift the hook into desired sub surface of water level which also indicates that if the fish is baited or not. Earth warm and small prawn is used as bait. Main fish species caught by this type of gear are Kalibaus (Labeo calbasu), Koi (Anabas testudineus), Shing (Heteropneustes fossilis), Punti (Puntius spp.), Rita (Rita rita), Tengra (Mystus vittatus) and some carp species.

Chara Barshi: Chara barshi was a long line measuring from 400 to $600 \mathrm{~m}$, which is set into shallow water with bamboo pools 4 to $6 \mathrm{~cm}$ above water. A small line of 0.45 to $1 \mathrm{~m}$ with barbed hooks is lowered into water with bait. The baits include earthworm, prawn and punti. One daun may contain even more than 500 hooks. The lines are shot at night and hauled in the morning. The small barshi was 1-2.0 cm, medium barshi was $4-5 \mathrm{~cm}$ and large barshi can be $6-8 \mathrm{~cm}$ insize. Different types of fish are caught by this gear but the main species are Ayre (Sperata aor), Pangus (Pangasius pangasius) and Taposhi (Polynemus paradiseus), Poa (Otolithoides pama), Boal (Wallago attu) and Tengra (Mystus vittatus).The efficiency of the gear is high and the catch composition of the gear was 4 to $6 \mathrm{~kg}$ per day.

Wounding Gear: Koach: Koach having more than 10 pieces of bamboo splits are firmly fixed in a bunch. The pointed ends of the bamboo splits are covered with sharp and pointed iron caps to increase the efficiency. The koach is thrown at the fish with great force so that the prongs pierce the fish. It is normally operated by the fishermen from a boat or embankment. It was operated in shallow water to catch bottom and pelagic fishes. The sharp end of the prong wounds the fish. It was found to operate during high flooding period when large fishes moved close to water surface near the land. Fish caught by this gear are Boal (Wallago attu), Shol (Channa striatus), Gozar (Channa marulius), Taki (Channa punctatus).The catch composition of the gear was 1 to 2 kg per day (Figure 4).
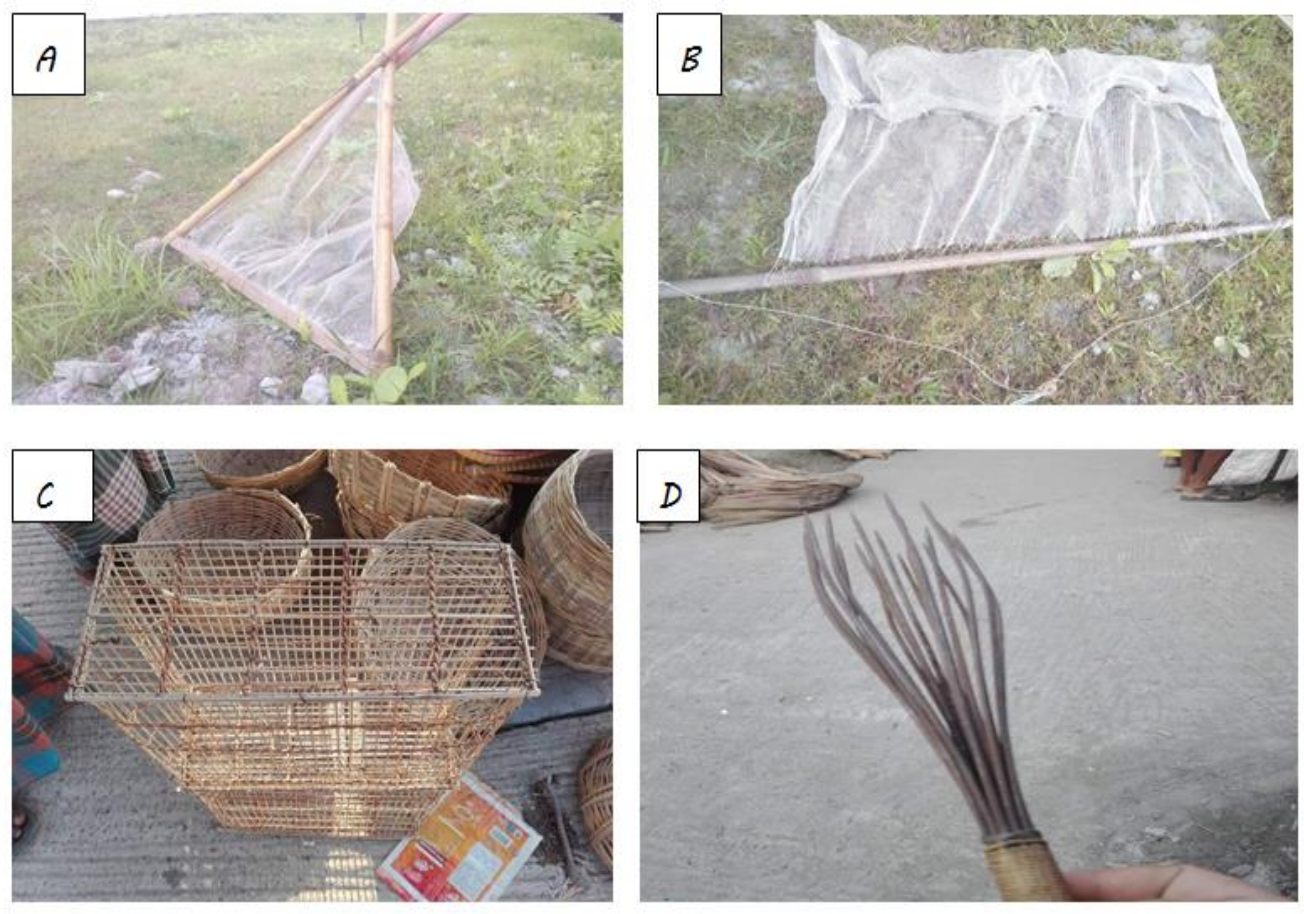

Figure 4: Fishing gear A -Thela jal, B-Moiya jal, C-Anta and D-Koach.

\section{Fish Species Composition on this Net}

There are 46 fish species belonging to 24 families were caught by these nets. Wide range sizes of fish species were caught by the net. The species caught by these following net and their fishing method are given in Table 2 . 


\section{International Journal of Oceanography \& Aquaculture}

\begin{tabular}{|c|c|c|c|}
\hline Family Name & Scientific Name & Local Name & $\begin{array}{l}\text { Fishing Method } \\
\end{array}$ \\
\hline \multirow{4}{*}{ Clupeidae } & Tenualosa ilisha & Ilish & Current Jal, Chandi Jal, Behundi jal, Ber Jal \\
\hline & Tenualosa toli & Toli Ilish & Poa Jal, Current Jal \\
\hline & Corica soborna & Kachki & Behundi Jal, Dharma Jal \\
\hline & Gudusia chapra & Chapila & Poa Jal, Ramsos Jal, Ber Jal \\
\hline \multirow{9}{*}{ Cyprinidae } & Puntius ticto & Tit punti & Behundi Jal, Dharma Jal \\
\hline & Salmostoma bacaila & Chela & Behundi Jal, Dharma Jal, Thela Jal \\
\hline & Esomus danricus & Darkina & Behundi Jal, Jhaki Jal, Thela Jal \\
\hline & Labeo bata & Bata & Behundi Jal, Dharma Jal, Jhaki Jal \\
\hline & Labeo rohita & Rui & Ayre Jal, Poa Jal, Current Jal \\
\hline & Gibelion catla & Catla & Ayre Jal, Poa Jal, Current Jal \\
\hline & Devario devario & Bashpata & Behundi Jal, Dharma Jal, Thela Jal \\
\hline & Rohtee cotio & Dhela & Behundi Jal, Moiya Jal, Jhaki Jal \\
\hline & Amblypharyngodon microlepis & Mola & Behundi Jal, Dharma Jal, Jhaki Jal \\
\hline \multirow{2}{*}{ Engraulidae } & Setipinna phasa & Phaisa & Current Jal, Poa Jal, Ramsos Jal \\
\hline & Thryssa purava & Ramsos & Ramsos Jal, Poa Jal, Behundi Jal \\
\hline Belonidae & Xenentodon cancila & Kakila & Behundi Jal, Poa Jal, Current Jal \\
\hline Cobitidae & Lepidocephalichthys guntea & Gutum & Behundi Jal, Dharma Jal, Jhaki Jal \\
\hline Notopteridae & Chitala chitala & Chitol & Ayre Jal, Poa Jal, Current Jal \\
\hline Ambassidae & Chanda ranga & Lal Chanda & Behundi Jal, Dharma Jal, Thela Jal \\
\hline Anabantidae & Anabas testudineus & Koi & Current Jal, Jhaki Jal, Moiya Jal \\
\hline \multirow{3}{*}{ Channidae } & Channa punctatus & Taki & Current Jal, Thela Jal, Behundi Jal \\
\hline & Channa marulius & Gojar & Current Jal, Poa Jal, Dharma Jal \\
\hline & Channa striatus & Shol & Current Jal, Poa Jal, Behundi Jal \\
\hline \multirow{4}{*}{ Gobiidae } & Glossogobius giuris & Bele & Ramsos Jal, Behundi Jal, Ber Jal \\
\hline & Pseudapocryptes elongatus & Cheua & Behundi Jal, Ber Jal \\
\hline & Odontamblyopus rubicundus & Lal Cheua & Behundi Jal, Ber Jal, Chargara Jal \\
\hline & Taenioides cirratus & Dogri & Moiya Jal, Behundi Jal Jhaki Jal \\
\hline Latidae & Lates calcarifer & Coral & Ayre Jal, Current Jal, Chargara Jal \\
\hline Nandidae & Nandus nandus & Vheda & Behundi Jal, Dharma Jal, Jhela Jal \\
\hline Osphronemidae & Trichogaster fasciata & Khailsa & Behundi Jal, Dharma Jal, Jhaki Jal \\
\hline Polynemidae & Polynemus paradiseus & Tapasi & Chandi Jal, Current Jal, Poa Jal \\
\hline Sciaenidae & Otolithoides pama & Lal Poa & Poa Jal, Ramsos Jal, Current Jal \\
\hline \multirow{3}{*}{ Bagridae } & Mystus vittatus & Tengra & Behundi Jal, Chargara Jal, Dharma Jal \\
\hline & Sperata aor & Ayre & Ayre Jal, Current Jal, Poa Jal \\
\hline & Rita rita & Rita & Current Jal, Behundi Jal, Ber Jal \\
\hline Sillaginidae & Sillaginopsis panijus & Tular dandi & Dandi Jal, Ramsos Jal, Current Jal \\
\hline Heteropneustidae & Heteropneustes fossilis & Shing & Behundi Jal, Chargara Jal, Dharma Jal \\
\hline Pangasiidae & Pangasius pangasius & Pangas & Current Jal, Ayre Jal, Poa Jal \\
\hline \multirow{2}{*}{ Siluridae } & Ompok pabda & Madhu Pabda & Chargara Jal, Thela Jal, Behundi Jal, Dharma Jal \\
\hline & Wallago attu & Boal & Ayre Jal, Current Jal, Poa Jal \\
\hline \multirow{2}{*}{ Schilbeidae } & Silonia silondia & Silon tengra & Behundi Jal, Dharma Jal, Current Jal \\
\hline & Ailia coila & Kajuli & Behundi Jal, Chargara Jal, Dharma Jal \\
\hline Mastacembelidae & Macrognathus aculeatus & Tara baim & Behundi Jal, Dharma Jal, Moiya Jal \\
\hline \multirow[t]{2}{*}{ Synbranchidae } & Monopterus cuchia & Kuchia & Behundi Jal, Dharma Jal, Moiya Jal \\
\hline & Macrobrachium rosenbergii & Golda chingri & Behundi Jal, Chargara Jal, Moiya Jal \\
\hline Palaemonidae & Macrobrachium lamarrei & Choto chingri & Behundi Jal, Chargara Jal, Moiya Jal \\
\hline
\end{tabular}

Table 2: Fish Species composition at study area. 


\section{International Journal of Oceanography \& Aquaculture}

Table 2 shows that wide ranges of fish species were caught by the different fishing gears. There were 46 fish species under 24 families were identified. Among the 24 family most number of fish species (9) caught under cyprinidae family and most number of the fish species (27) caught by Behundi Jal, Ber Jal and Dharma Jal. And lower number of the fish species (3) caught by Ayere Jal. In the 46 fish species Choto chingri (Macrobrachium lamarrei), Elish (Tenualosa ilisha) and Poa (Otolithoides pama) were caught by the maximum number $(7,6$, and 5 respectively) of net. Among that net Behundi Jal is the most destructive fishing gear in this region, along with Chargara Jal, Current Jal, Ber Jal is also destructive fishing gear because mesh size of this net is very short and they caught wide range size of fishes. Behundi Jal caught huge amount of fry and also fingerling to adult that is most harmful for the biodiversity of the Payra River.

\section{Discussion}

The fishery of the Payra River is multispecies and multigear in nature. Different types of fishing net were used in different seasons for fishing of the study area. The use of fishing net is higher during the monsoon period and post monsoon period because the availability of fishes is higher during this period. Type of nets, their lengths, depths and mesh sizes vary depending on choice and capital of the persons involved in commercial fishing as well as the abundance of fish.

From the study area there were identified thirteen types of fishing net under the six major categories of net. The name of the net is Gill net (Chandi Jal,Poa Jal, Dandi Jal, Ramsos Jal, Ayre Jal and Current Jal), Seine net (Ber jal), Fixed purse net (Benti jal and Chargora jal), Lift nets (Dharma jal), Push net (Thela jal and Moiya jal), Cast net (Jhaki jal). Under the following net there were about 46 types of fish species belonging to 24 families were identified in the catches during the study period. The study period was during post monsoon period of the year.

In another study Rahman MM, et al. [7] identified 57 fish species under 28 families in Payra River along Patuakhali sadar Upazila. The study period was one year long. In the study of Rahman, et al. they identified 14 fishing net under 6 major categories and Sultana MA, et al. [8] identified 12 net under 6 major categories respectively in the Payra River along Patuakhali sadar upazila and Amtali upazila. Their study period was twelve months long. In the study of Rahman MM, et al. identified Sutar Jal, shine Jal and Chor Jal which is absence in my study area, with that I identified Ayer Jal, Dandi Jal and
Ramsos Jal which is absence in Rahman MM, et al.'s study. In the study of Sultana, et al. they identified Coral Jal which is absence in my study along with in my study I identified Current Jal, Dandi Jal which is absence in the Sultana, et al.'s study. The study of Miah MI, et al. [9] they identified 6 fishing net under 4 major categories in Shitalakshya River at Siddirgonj area in Narayangonj District. The study was conduct during pre-monsoon period and it was twelve week long in the Shitalakshya River. In the study of Miah MI, et al. there were identified 20 fish species under 11 families.

The mesh size of different net also varies from river to river even in the same river at the different area. The study was conducted during the post monsoon period for the reason the catch per day was higher in Chandi Jal, Poa Jal, Dandi Jal, Ramsos Jal, Ayre Jal, Current Jal, Ber jal, Behundi Jal, Chargora jal, Dharma jal, Thela jal, Moiya jal, and Jhaki jal is $22.5,6,5.5,8,9.5,13.5,8.5,16.5,8.5,4,1.5$, $2.5,2.5 \mathrm{~kg}$ respectively (Table 1 ). It is higher than Rahman MM, et al. [7] who identified in Poa Jal, Current Jal, chandi Jal, Ber Jal, Behundi Jal, Chargara Jal, Jhaki Jal, Dharma Jal, Moiya Jal, Thela Jal is 5, 4.5, 20, 7.5, 6.5, 5, 2, 3, 2, $1.5 \mathrm{~kg}$ respectively. Among the fishing net Behundi Jal, Current Jal, Ber jal and Chargara Jal is most destructive fishing gear. The mesh size of these net is very short and this destructive fishing gear caught a wide ranges of fish species (27 among 46) which sizes is all stage of fish life from fry to adult. That is threat for biodiversity of the Payra River. Some other fishing gears are efficient to fisherman and not threat for biodiversity of the Payra River.

\section{Conclusion}

Payra River is a kind of river which plays a significant role to the local people by providing a considerable amount of fish as their source of protein. It also provides financial support for surrounding people of the river. There were different types of fishing gears to catch different species but only eighteen types of fishing gear found to catch fish. Though there were various types of fishing net only eight were dominant and many overlapping species were caught by this gear. The mesh size of the net varied from smaller (less than $1 \mathrm{~cm}$ ) very bigger (more than $8 \mathrm{~cm}$ ). So various sized fishes were caught. The study identified there were forty-six fish species under twenty-four families of fish were caught by thirteen types of fishing net under six major categories. In the study area there was observed some destructive fishing gear which is threat for existing fish fauna. So should be restricted the use of destructive fishing gear 


\section{International Journal of Oceanography \& Aquaculture}

and control overfishing, that can save some endanger species of the river. The introduction of fishing gear and methods to an area whether these methods are technically new are not without danger to both the community and the aquatic ecosystem. In this regards, the fishing arts developed within a region may usually be the best suited for the species and sizes desired, given the prevailing aquatic conditions, community and economic structure. The adaptation of new technologies could help small scale fisheries increase their catch, but the introduction of any new fishing technology always demands good rational management and regulation. Upgrading the gear and making it more efficient increases the risk of further depleting the fish stocks. As the operation of all types of gear cannot be banned immediately to allow the stocked fingerlings to grow out, it is important to identify the gear that can be make harmful effect on stock that should be banned. At the same time, an awareness or training program should be conducted under the supervision of the government as well as non- government organizations to the fishermen to create awareness of the long-term effects of different fishing gears and to impart knowledge of fishing laws. Therefore, the introduction of new gear and fishing methods should be accompanied by proper monitoring and protection of the aquatic resources.

\section{References}

1. DoF (2013) Jatiya Matshya Saptah. Department of Fisheries, Government of the People's Republic of Bangladesh.

2. DoF (2015) National fish week compendium. Department of Fisheries, Ministry of Fisheries and Livestock, Government of the People's Republic of Bangladesh: 1-144.

3. Hussain MG, Mazid MA (2001) Genetic improvement and conservation of carp species in Bangladesh.
Bangladesh Fisheries Research Institute and International Center for Aquatic Resources Management (ICLARM): 1-74.

4. Islam MA, Hossain MM, Ahsan ME, Nahar A (2015) Status and current worries of fish diversity in the Paira River, Patuakhali, Bangladesh. International Journal of Fisheries and Aquatic Studies 2(3): 160165.

5. Chakraborty SC, Hossain MA, Hoq ME (1995) Traditional inland fishing methods in Bangladesh Journal of Asiatic Society of Bangladesh, Science 1(1): 19-27.

6. Hameed MS, Boophendranath MR (2000) Modern Fishing Gear Technology. Das Publishing House, Dellhi, pp: 3.

7. Rahman MM, Rahman MB, Akhter Rithu MN, Hoque MS (2016) Observation on selectivity of fishing gears and ichthyofaunal diversity in the Paira River of Southern Bangladesh. International Journal of Fisheries and Aquatic Studies 4(1): 95-100.

8. Sultana MA, Mazumder SK, Kunda M (2016) Fishing Gears and Crafts Used in Payra River, Bangladesh. European Journal of Applied Sciences 8(6): 337-346.

9. Miah MI, Ferdausi R, Hasan KR, Siddiq MA, Farid SM (2010) Species composition and gear used in fishing during pre-monsoon period in the Shitalakshya river at Siddirgonj area, Narayangonj, J Agrofor Environ 4(1): 71-73.

10. Banglapedia (2015) Patuakhali Upazila, National Encyclopedia of Bangladesh. Asiatic Society of Bangladesh, Dhaka. 